\title{
Giant Bark Aphid, Longistigma caryae (Harris) (Insecta: Hemiptera: Aphididae) ${ }^{1}$
}

H. A. Denmark ${ }^{2}$

\section{Introduction}

This bark-feeding aphid was first described by Harris (1841) as Aphis caryae from pignut hickory, Carya glabra (= porcina) (Mill.) Sweet, in Massachusetts. It is the largest aphid that occurs in the United States, and it was probably this species that was reported by Thomas (1879) from limbs of pignut hickory in Illinois. Weed (1891) described its various forms and gave a short note on its biology. Wilson (1909) described the genus Longistigma for this species because of the extremely long slender stigma which extends around the end of the wing.

\section{Distribution}

L. caryae has been reported from Alabama, Arkansas, Arizona, California, Connecticut, Delaware, District of Columbia, Florida, Georgia, Illinois, Indiana, Iowa, Kansas, Kentucky, Louisiana, Maryland, Massachusetts, Michigan, Minnesota, Mississippi, Missouri, Nebraska, New Jersey, New Mexico, New York, North Carolina, Ohio, Pennsylvania, South Carolina, Tennessee, Texas, Utah, Virginia, and Wisconsin.

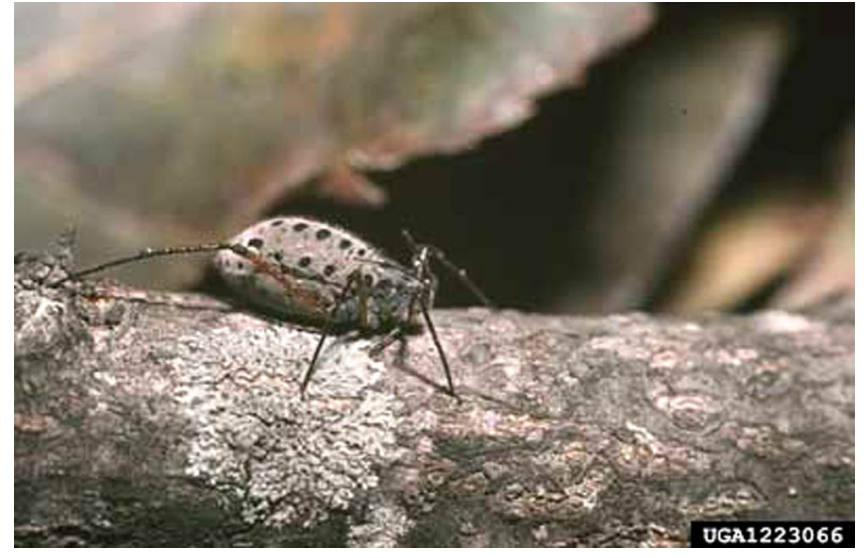

Figure 1. Nearly mature nymph of the giant bark aphid, Longistigma caryae (Harris). Credits: Louis Tedders, USDA ARS, courtesy of Forestrylmages.org

\section{Description}

Apterous (wingless) viviparous female: body 6 $\mathrm{mm}$ long, abdomen $3.5 \mathrm{~mm}$ in diameter, antennae 3 $\mathrm{mm}$ long, posterior legs $9 \mathrm{~mm}$ long. Light to dark brown except cornicles and a few small spots on the abdomen; tips of femora, tibia and tarsi black. Cornicles very short and truncate. Rostrum extending to posterior coxae. Body, legs and antennae with

1. This document is EENY-292 (originally published as DPI Entomology Circular 212), one of a series of Featured Creatures from the Entomology and Nematology Department, Florida Cooperative Extension Service, Institute of Food and Agricultural Sciences, University of Florida. Published: June 2003. Revised: May 2004. This document is also available on Featured Creatures Website at http://creatures.ifas.ufl.edu. Please visit the EDIS Website at http://edis.ifas.ufl.edu. Additional information on these organisms, including many color photographs, is available at the Entomology and Nematology Department website at http://entnemdept.ifas.ufl.edu/.

2. H. A. Denmark, Florida Department of Agriculture and Consumer Services, Division of Plant Industry, Gainesville.

The Institute of Food and Agricultural Sciences (IFAS) is an Equal Employment Opportunity - Affirmative Action Employer authorized to provide research, educational information and other services only to individuals and institutions that function without regard to race, creed, color, religion, age, disability, sex, sexual orientation, marital status, national origin, political opinions or affiliations. For information on obtaining other extension publications, contact your county Cooperative Extension Service office. Florida Cooperative Extension Service / Institute of Food and Agricultural Sciences / University of Florida / Larry R. Arrington, Interim Dean 
long, light brown hairs. Antennal segment III equal to IV plus V; VI short, with unguis thumb-shaped.

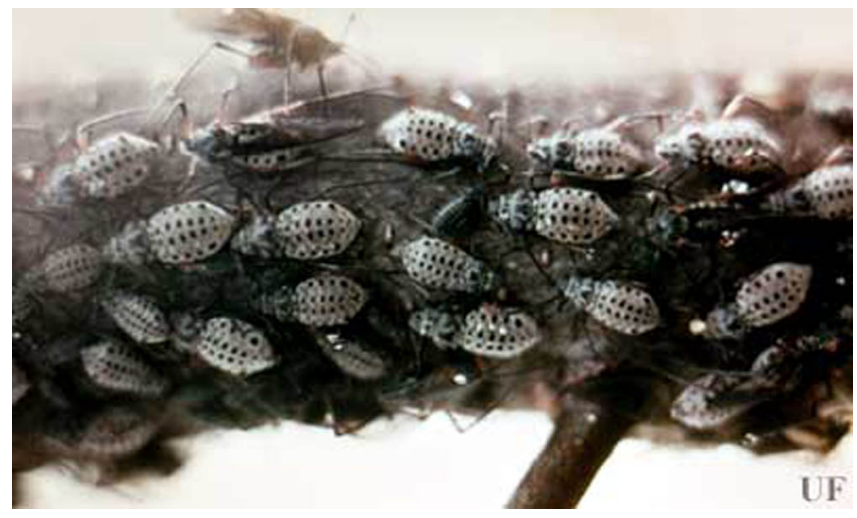

Figure 2. Colony of giant bark aphids, Longistigma caryae (Harris), with both winged and wingless females. Credits: University of Florida

Alate (winged) viviparous female: body $6 \mathrm{~mm}$ long, abdomen 3 to $5 \mathrm{~mm}$ in diameter, head to tip of folded wings $10 \mathrm{~mm}$; wing expanse $18 \mathrm{~mm}$, antennae $3 \mathrm{~mm}$, posterior legs $11 \mathrm{~mm}$. Head and thorax bluish black, antennae and cornicles black, dorsum of abdomen whitish with 2 rows of black spots on each side of the median line and a transverse series of small, black dots on each segment. Cornicles short and truncate. Tips of femora, tibia and tarsi black. Body, legs and antennae covered with long brown hairs. Wings dusky, especially toward base.

Oviparous females do not differ in appearance from viviparous females.

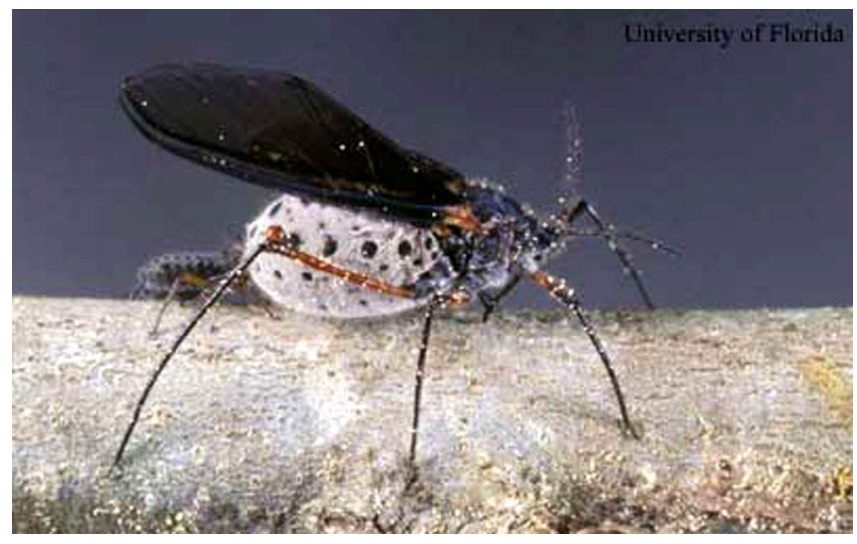

Figure 3. Winged adult giant bark aphid, Longistigma caryae (Harris). Credits: Lyle J. Buss, University of Florida

\section{Hosts}

Basswood - Tilia spp., hickory - Carya spp., oak - Quercus spp., pecan - Carya illinoensis

(Wangenheim) Koch, sycamore - Platanus spp.,

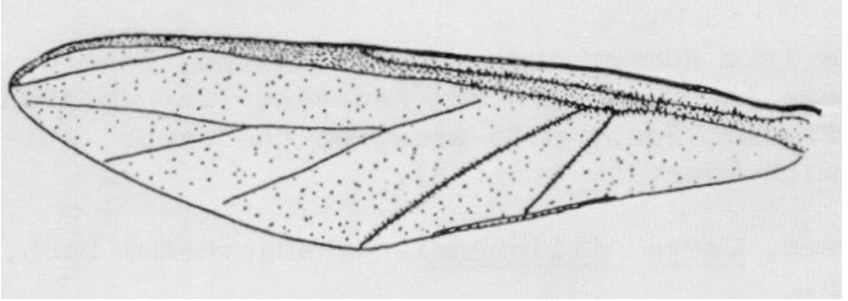

Figure 4. Forewing. Credits: Division of Plant Industry

walnut - Juglans spp. and wax myrtles (Barnard and Dixon, Mueller 2002).

\section{Economic Importance}

During the late summer and autumn months, numerous specimens feeding on branches excrete large amounts of a sticky, clear liquid known as honeydew that can form a sticky coating on automobiles, picnic tables, lawn furniture, and plants underneath trees where the aphids are feeding. Soon sooty mold, which is grey-black in color, begins to grow on the sugar-rich honeydew. While sooty mold does not directly damage plants, it blocks sunlight and disrupts photosynthesis, contributing to reduce plant vigor. Sooty mold can also damage the finish on cars, chairs, tables or other objects.

\section{Survey and Detection}

Look for sooty mold on any of the host plants. Check the bark of limbs and trunk for large dark aphids during the summer and early autumn.

\section{Management}

For management information please see Insect Management on Landscape Plants (http://edis.ifas.ufl.edu/IG013).

\section{Selected References}

Barnard EL, Dixon WN. (October 1983). Giant bark aphid. Insects and Diseases: Important Problems of Florida's Forest and Shade Tree Resources. http://www.fl-dof.com/Pubs/Insects_and_Diseases/ insects_hbs_giant_bark_aphid.htm (9 June 2003).

Harris TW. 1841. A Report on the Insects of Massachusetts, Injurious to Vegetation. (1842 Reprint: A Treatise on Some of the Insects of New England, Which are Injurious to Vegetation. Cambridge), $459 \mathrm{p}$. 
Mueller CW. (March 2002). Giant bark aphids.

Horticulture Update.

http://aggie-horticulture.tamu.edu/extension/

newsletters/hortupdate/mar02/art2mar.html (9 June 2003).

Thomas C. 1879. Eighth report of the state entomologist on the noxious and beneficial insects of the State of Illinois. Third Annual Report, 212 p.

Weed CM. 1891. Fifth contribution to a knowledge of certain little-known Aphididae. Insect Life 3: 285-293.

Wilson HF. 1909. Notes on Lachnus caryae Harris under a new name. Canadian Entomologist 41: 385-387. 